\title{
Production of L-Asparaginase (L-ASN) from endophytic Lasiodiplodia theobromae hosted Teucrium polium in Egypt
}

\author{
Balbool BA ${ }^{1^{*}}$, Abdel-Azeem $\mathrm{AM}^{2}$, Moubasher $\mathrm{MH}^{3}$ and Helmy $\mathrm{EA}^{4}$ \\ ${ }^{1}$ Microbiology Department, October University for Modern Sciences and Arts, 6th October, Egypt. \\ ${ }^{2}$ Botany Department, Faculty of Science, Suez Canal University, Ismailia 41522, Egypt. \\ ${ }^{3}$ Botany and Microbiology Department, Faculty of Science, Cairo University, Giza, Egypt. \\ ${ }^{4}$ The Regional Center for Mycology and Biotechnology, Al-Azhar University, Cairo, Egypt.
}

Balbool BA, Abdel-Azeem AM, Moubasher MH and Helmy EA 2018 -Production of LAsparaginase (L-ASN) enzyme from endophytic Lasiodiplodia theobromae hosted Teucrium polium in Egypt. Microbial Biosystems 3(2), 46-55.

\begin{abstract}
Endophytic fungi produce important bioactive primary and secondary metabolites. Researchers used L-Asparaginase for the treatment of Acute Lymphoblastic leukemia (ALL). Endophytic taxon, Lasiodiplodia theobromae (Pat.) Griff. and Maubl. has been isolated from Teucrium polium plant tissues collected from Saint Katherine Protectorate and was screened for its ability to produce L-Asparaginase qualitatively and quantitatively. The crude enzyme has been partially purified using gel-filtration Sephadex G-100 with an activity of $21.00 \mathrm{lMmL}^{-1}$ $\min ^{-1}$. The results revealed that $L$. theobromae (SCUF-TP2016) represents a rich source of bioactive metabolites that can be manipulated to produce L-Asparaginase which is a desirable novel analog for chemotherapy.
\end{abstract}

Key words - Anti-leukemic, enzymes, Saint Katherine Protectorate, gel filtration.

\section{Introduction}

Endophytic fungi are group of endobionts that live asymptotically inside plant tissues for some time (Strobel and Daisy 2003). Such mutualistic relation between both of the host plant and endophytes lead to a benefits for both sides (Zhao et al. 2010), where endophytes would create such defense mechanism for the host plant by the production of several biologically active compounds that would used in the field of industry, medicine and agriculture (Chow and Ting 2015).

Several studies have been carried to reveal the relation between the active compounds produced by some plants and the associated endophytic fungi and it came out with a conclusion that they are very closely related, where the endophytic fungi would produce the same active compound produced by the host plant and likely it was found to be sometimes much more active than the host plant itself (Strobel and Daisy 2003; Gunatilaka 2006; Suryanarayanan et al. 2009; Pandey et al. 2014).

Acute lymphoblastic leukemia (ALL) considered one of the most common cancer diseases among children; it's characterized by the over production of immature white blood cells (Neoplastic), such cells prevent the bone marrow from the formation of normal white blood cells. It cannot function properly toward any infections. ALL would occur at any age but much more common the age of (0-14 years) representing around $60 \%$ of the infected cases. Neoplastic

Submitted 20 September 2018, Accepted 27 December 2018, Published online 31 December 2018 46 Corresponding Author: Balbool BA- e-mail - bbalbool@msa.eun.eg

This is an open access article distributed under the terms of the Creative Commons Attribution License, which permits unrestricted use, distribution, and reproduction in any medium, provided the original author and source are credited. 
cells lack L-asparagine synthetase which leads to prevention of asparagine synthesis, in the mean neoplastic cells require high amounts of L-asparagine to proliferate. Thus they depend on external sources for asparagine, preventing the neoplastic of the asparagine will lead to the starving of the neoplastic cells and die off (El-Nagga et al. 2014; Sanjotha and Manawadi 2017).

L-Asparaginase belongs to the amidase family (EC 3.5.1.1) which is responsible for the hydrolysis of L-asparagine into ammonia and aspartic acid (Dias et al. 2016), such enzyme is widely distributed among several organisms of Prokaryotic and Eukaryotic sources (Kumar and Sobha 2012; Kumar et al. 2013)

Due to the mode of enzyme action previously described, it would have an important role in the treatment of ALL. Different taxa of fungi have been screened for the production of LAsparaginase as a safe alternative source for e.g. Aspergillus, Penicillium and Fusarium (Sarquis et al. 2004; Baskar and Renganathan 2009).

Unlikely, few studies carried by Egyptian researchers on endophytic fungi producing Lasparaginase in Egypt such as Moharram et al. (2016), continuing search for endophytic fungi hosted medicinal plants in Saint Katherine, Egypt. During the presented study Lasiodiplodia theobromae (SCUF-TP2016) which is recovered from Teucrium polium showed a remarkable potentiality for the production of extracellular L-Asparaginase by an endophytic native isolate of.

\section{Materials and Methods Sampling}

Vegetative shoots of Teucrium polium L. were collected from 10 sites representing different elevation wadis (1290 meters above sea level (m.a.s.l.) up to 1800 m.a.s.l.) in Saint Katherine Protectorate, Sinai, Egypt, following the ethical rules of the protectorates. Samples were collected in sterile polyethylene bags, closed using rubber bands, and transferred to the laboratory until plating.

\section{Isolation and identification of endophytes}

The aerial parts of collected plant samples were washed in running water, cut into small pieces, immersed in $75 \%$ ethanol for 1 minute, dipped in sterile distilled water twice then 0.05 $\mathrm{g} / \mathrm{ml}$ of a sodium hypochlorite solution for 3-5 minutes, and rinsed three times in sterile distilled water (Abdel-Azeem and Salem 2012). The surface-sterilized segments were cultured on potato dextrose agar medium (PDA, Difco) amended with $0.05 \mathrm{~g} / \mathrm{L}$ rose Bengal and $150 \mathrm{mg} / \mathrm{L}$ chloramphenicol. Petri dishes were sealed using parafilm and incubated at $28 \pm 1^{\circ} \mathrm{C}$ for 7 to 21 days. Growing fungi were purified for identification.

\section{Phenotypic identification}

Phenotypic identification of endophytic fungal isolates were primarily based on the relevant identification keys for Penicillium (Pitt 1979), Aspergillus (Klich 2002), dematiaceous hyphomycetes (Ellis 1971, 1976), Fusarium (Leslie and Summerell 2006), miscellaneous fungi (Domsch et al. 2007), soil ascomycetes (Guarro et al. 2012), and Alternaria (Simmons 2007). The names of fungal taxa have been shortened in accordance to Kirk and Ansell (1992), and their systematic arrangement followed Ainsworth and Bisby's Dictionary of the Fungi (Kirk et al. 2008). All reported taxa were checked against Index Fungorum website database (Kirk 2018) for name corrections, authorities, and taxonomic assignments. All isolated taxa were deposited in Suez Canal University Fungarium (SCUF(http://www.wfcc.info/ccinfo/index.php/collection/by_id/1180/).

\section{Qualitative analysis}

All of the isolated species have been tested for the ability to produce L-Asparaginase. A modified technique used for the qualitative screening of L-asparaginase as follows; $5 \mathrm{~mm}$ fungal 
plug transferred into falcon tubes $(50 \mathrm{ml})$ contains $30 \mathrm{ml}$ of Modified Capek Dox medium (MCD). The tubes incubated for 5 days at $30 \mathrm{C}$, the color change recorded from yellow to blue taking in consideration the degree of color change, which gave a prediction on the amount of ammonia released (Mahajan et al. 2013).

\section{Quantitative assay}

To clean test tube $0.1 \mathrm{ml}$ of L-asparagine ( $40 \mathrm{mM}$ ), dissolved by shacking gently, $1 \mathrm{ml}$ of the crude sample extract (media after filtration), $0.5 \mathrm{ml}$ of $0.5 \mathrm{M}$ phosphate buffer ( $\mathrm{pH} 7.0$ ) and $0.4 \mathrm{ml}$ of $\mathrm{dH}_{2} \mathrm{O}$ were added. Enzyme sample was handled very carefully and kept on ice. The samples tubes were incubated at room temperature for 30 minutes. After 30 minutes, the reaction was stopped by the addition of $0.5 \mathrm{ml}$ trichloroacetic acid $1.5 \mathrm{M}$ (TCA), followed by centrifugation at 10,000 rpm for $5 \mathrm{~min}$. Pellet obtained was discarded. $3.7 \mathrm{ml}$ of distilled water was added to $0.1 \mathrm{ml}$ of supernatant solution. To this solution, Nessler's reagent was added (1 $\mathrm{ml}$ ); followed by vortex and incubation for $10 \mathrm{~min}$. Control was prepared containing all the other reagents except enzyme. Absorbance measured at $450 \mathrm{~nm}$, using standard curve of ammonia the amount of ammonia liberated from protein sample of interest calculated (Kumar et al. 2010).

\section{Partial purification of L-Asparaginase produced by Lasiodiplodia theobromae Large scale media cultivation}

The most potent L-Asparaginase-producing taxon; Lasiodiplodia theobromae was selected for further investigation. To get a large amount of crude extract of the L-asparaginase purified Lasiodiplodia theobromae inoculated into MCD media $(4 \mathrm{~L})$ without any indicators and incubated in shaking incubator at $120 \mathrm{rpm}$ for average 5 days at $30^{\circ} \mathrm{C}$. The obtained media filtered through sterile filter papers and then centrifuged for 10 minutes at $10,000 \mathrm{rpm}\left(4^{\circ} \mathrm{C}\right)$ to remove cell debris and mycelia.

\section{Protein precipitation}

The filtrate subjected to protein precipitation by using cold acetone technique in which acetone was kept at $-80^{\circ} \mathrm{C}$ prior to precipitation (Mahajan et al. 2014). Cold acetone was added to the culture filtrate of selected sample in ratio of $2 \mathrm{X}$ and it was incubated at $-20^{\circ} \mathrm{C}$ overnight. The next day, the samples were centrifuged at 13,000 rpm for 15 minutes. Supernatant was discarded and pellet obtained was weighed and dissolved in suitable volume of $0.5 \mathrm{M}$ phosphate buffer ( $\mathrm{pH} 7.0)$ and stored at $-80^{\circ} \mathrm{C}$ till further use.

\section{Gel-filtration purification (Sephadex G-100)}

The precipitated protein samples were loaded on column pre-equilibrated with sodium sulphate buffer 0.5M (pH7.0) Sephadex G 100. It was eluted with the same buffer, and fractions were collected at the flow rate of $1 \mathrm{ml} / \mathrm{min}$. Fraction viewing high activity were pooled and asparaginase activity was assayed by previously described assay method (Asha and Pallavi 2012).

\section{Results}

\section{General description and taxonomy of isolated endophytes}

During our study a total of 424 endophytic colony forming units (CFUs) isolated (Table 1) which represented by twelve genera, 16 species. Taxonomically the 16 species have been assigned to one phylum, two classes, five orders and five families. Order Pleosporales came first by recorded five species, followed by order Sordariales by four species, order Eurotiales by 3 species, and other orders recorded only one to two species. The species to genus ratio (S/G) per family showed that family Nectriaceae was the most diverse with a ratio of 2 , followed by family 
Aspergillaceae with a ratio of 1.5, Pleosporaceae and Chaetomiaceae with 1.3, and other families showed $\mathrm{S} / \mathrm{G}$ ratio of one (Table 2).

Regarding species richness during seasons; spring showed185 CFUs, Summer121CFUs, autumn71CFUs and Winter47CFUs (Fig. 1). While, regarding the species total count variations among the seasons it showed a remarkable variation over seasons for Alternaria alternata, Aspergillus flavus, Chaetomium nigricolor, Thielavia terricola and Aspergillus niger they showed no growth at winter, while for Lasiodiplodia theobromae, Alternaria phragmospora, Curvularia lunata, Preussia minimoides and Nigrospora oryzae they showed no growth in autumn (Fig.2).

Table 1 Fungi recorded, total counts (TC, calculated per 120 plates), percentage counts (\% C, calculated per total fungal catch), number of cases of isolation (NCI, per season) and occurrence remarks (OR) of all fungi recovered.

\begin{tabular}{lrrrl}
\hline \multicolumn{1}{c}{ Species } & TC & \%C & NCI & OR \\
\hline Alternaria alternata (Fr.) Keissl & 83 & 19.6 & 3 & M \\
Alternaria phragmospora Emden & 10 & 2.4 & 3 & M \\
Curvularia lunata (Wakker) Boedijn & 40 & 9.4 & 3 & M \\
Lasiodiplodia theobromae (Pat.) Griffon and Maubl. & 62 & 14.6 & 3 & $\mathrm{M}$ \\
Preussia minimoides (S.I. Ahmed and Cain) Valldos. and Guarro & 20 & 4.7 & 4 & $\mathrm{H}$ \\
Ulocladium tuberculatum E.G. Simmons & 20 & 4.7 & 4 & $\mathrm{H}$ \\
Aspergillus flavus Link & 10 & 2.4 & 3 & $\mathrm{M}$ \\
Aspergillus niger Tiegh. & 10 & 2.4 & 3 & $\mathrm{M}$ \\
Penicillium notatum Westling & 28 & 6.6 & 4 & $\mathrm{H}$ \\
Chaetomium brasiliense Bat. and Pontual & 15 & 3.5 & 4 & $\mathrm{H}$ \\
Chaetomium globosum Kunze & 15 & 3.5 & 3 & $\mathrm{M}$ \\
Chaetomium nigricolor L.M. Ames & 11 & 2.6 & 3 & $\mathrm{M}$ \\
Fusarium oxysporum sensu Smithand Swingle & 50 & 11.8 & 4 & $\mathrm{H}$ \\
Fusarium solani (Mart.) Sacc. & 10 & 2.4 & 3 & $\mathrm{M}$ \\
Nigrospora oryzae (Berk. and Broome) Petch & 10 & 2.4 & 3 & $\mathrm{M}$ \\
Thielavia terricola(J.C. Gilman and E.V. Abbott) C.W. Emmons & 30 & 7.1 & 4 & $\mathrm{H}$ \\
Total & 424 & 100.0 & 54 & \\
\hline Oct. & & &
\end{tabular}

Occurrence remarks (OR): H: high,3-4 of the seasons; M: moderate,2-3; L: low,1-2,R:rare,0-1.

Table 2 Taxonomic assignment of the isolated taxa according to Kirk et al. (2008)

\begin{tabular}{|c|c|c|c|c|c|c|}
\hline Phylum & Class & Order & Family & Genus & Species & $\mathrm{S} / \mathrm{G}$ \\
\hline \multirow{7}{*}{ Ascomycota } & \multirow{3}{*}{ Dothideomycetes } & \multirow{2}{*}{ Pleosporales } & Pleosporaceae & 3 & 4 & 1.3 \\
\hline & & & Sporormiaceae & 1 & 1 & 1.0 \\
\hline & & Botryosphaeriales & Botryosphaeriaceae & 1 & 1 & 1.0 \\
\hline & \multirow{4}{*}{ Eurotiomycetes } & Eurotiales & Aspergillaceae & 2 & 3 & 1.5 \\
\hline & & Sordariales & Chaetomiaceae & 3 & 4 & 1.3 \\
\hline & & Hypocreales & Nectriaceae & 1 & 2 & 2.0 \\
\hline & & Incertae sedis & Incertae sedis & 1 & 1 & 1.0 \\
\hline Total & 2 & 5 & 5 & 12 & 16 & \\
\hline
\end{tabular}




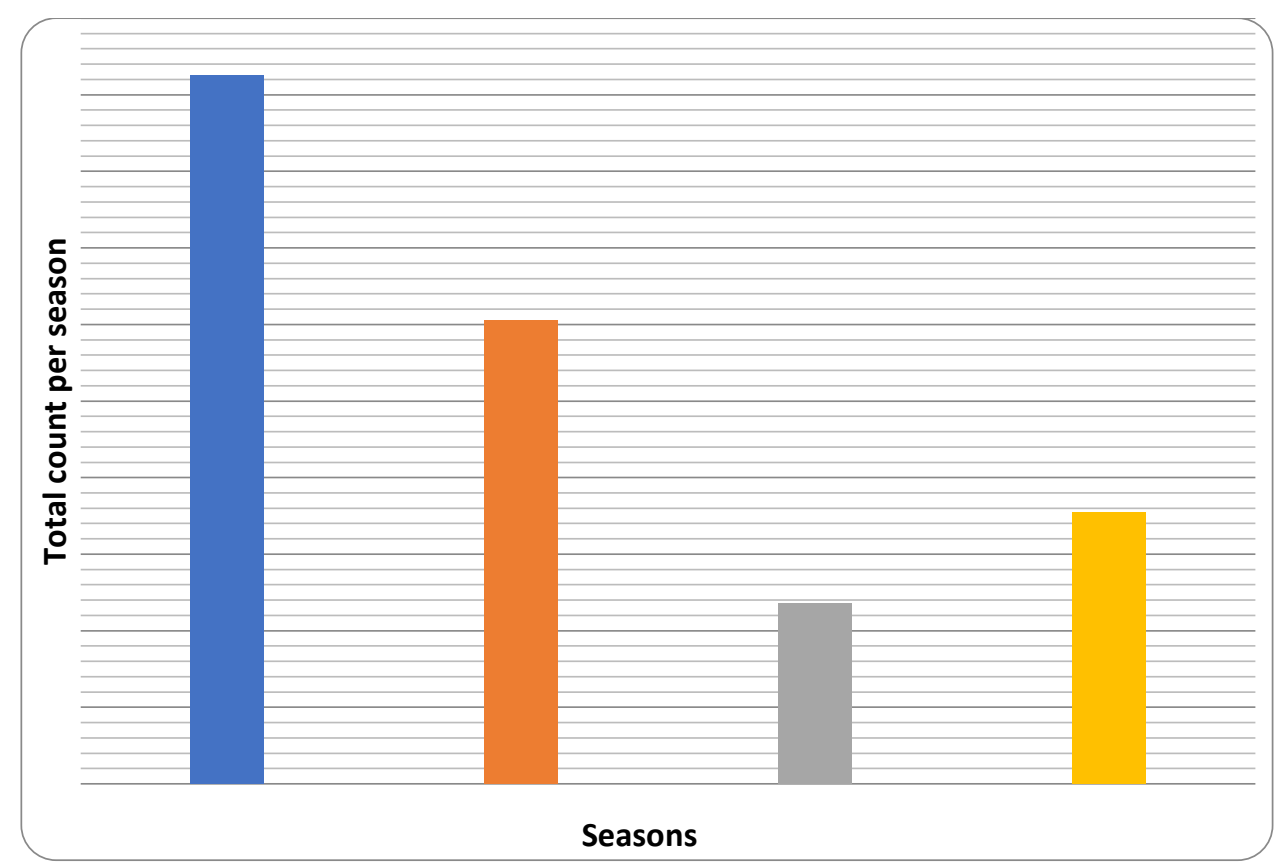

Fig. 1 -The total count of the isolated species among four seasons represented as CFU.

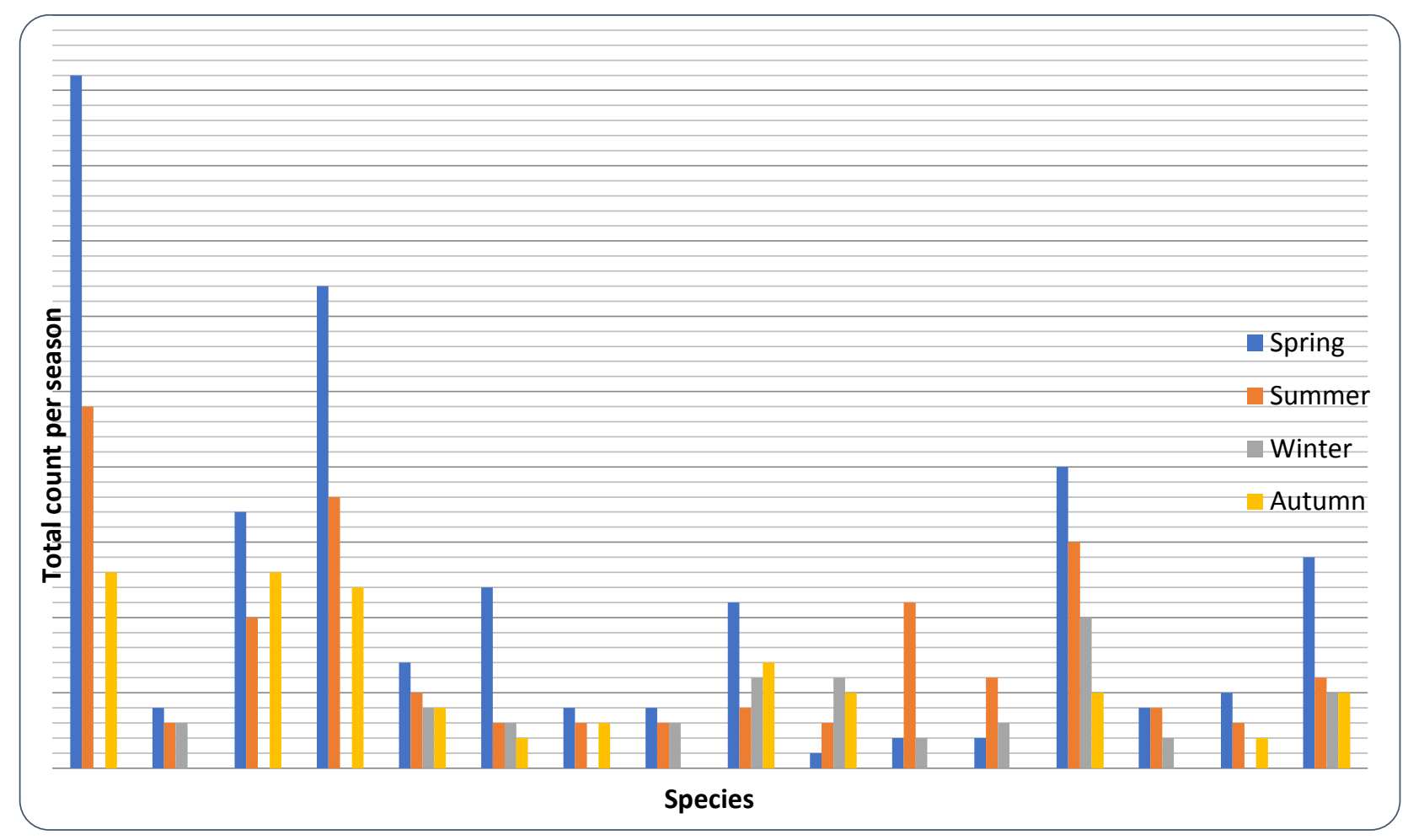

Fig. 2 -The total count of the isolated taxa among four seasons.

Regarding the isolates total count over the four seasons Alternaria alternata showed the highest count with 83 colonies, while Alternaria phragmospora, Chaetomium nigricolor, Curvularia lunata, Preussia minimoides and Thielavia terricola showed the lowest count with 10 colonies, others showed a moderate count (Fig.3). 


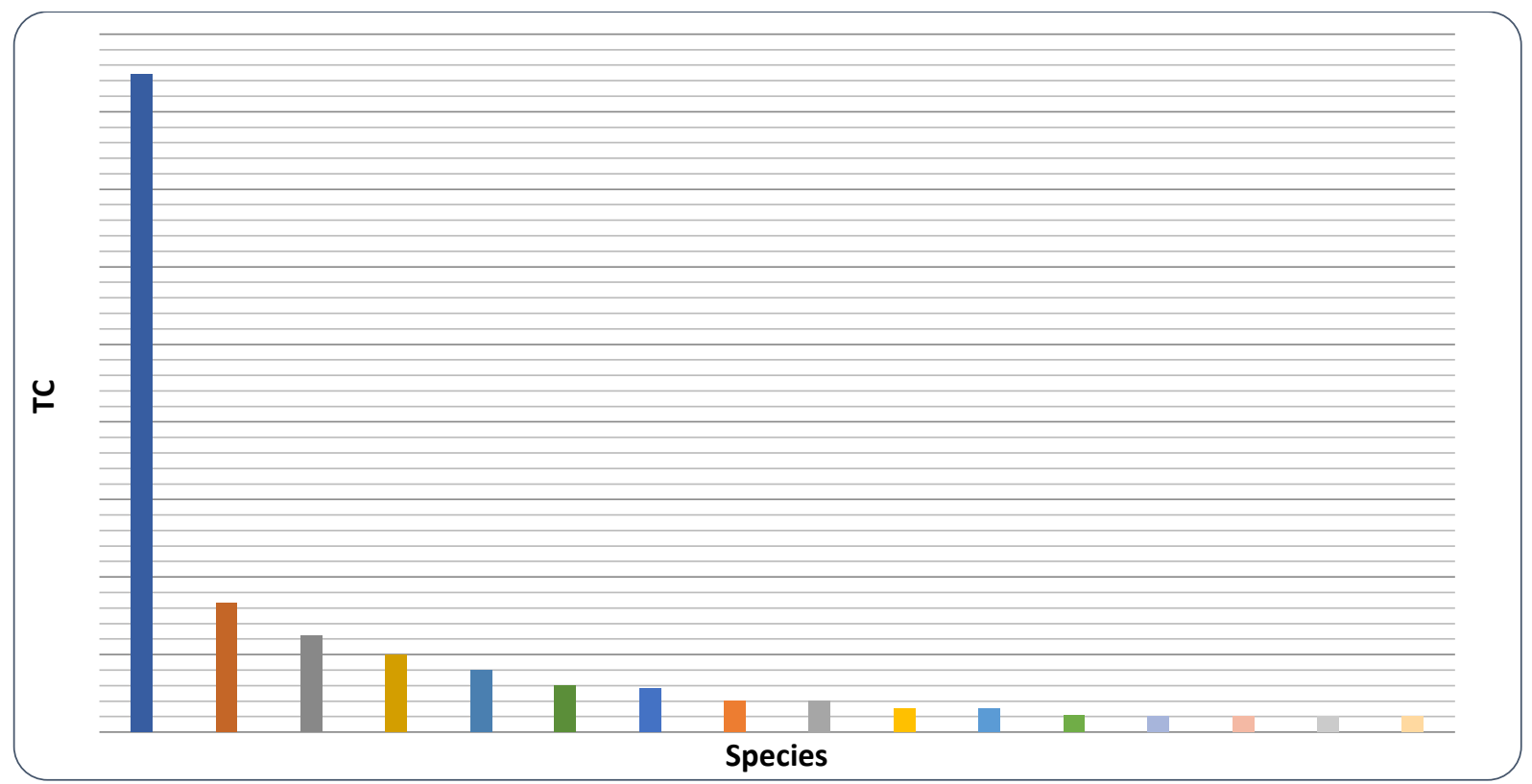

Fig. 3 -The total count of the sixteen isolated taxa during the study.

\section{Qualitative screening of L-asparaginase}

Out of the 16 isolated endophytes only three showed L-asparaginase activity on MCD broth, which have been detected by the change of the yellow color of media (acidic) to blue color (basic) due to the production of ammonia from the hydrolysis process of asparagine to aspartic acid and ammonia, where ammonia lead to the increase of $\mathrm{pH}$ toward basic status, which in return change the Bromothymol blue indicator color from yellow to blue, which indicated the presence of L-Asparaginase.

\section{Quantitative screening of L-asparaginase}

Positive isolates gave activity range from 0.55 to $31.5 \mathrm{lMmL}^{-1} \mathrm{~min}^{-1}$, individually Fusarium oxysporum (0.55), Fusarium solani (0.89), where Lasiodiplodia theobromae recorded the highest activity (31.5).

\section{Phenotypic description of Lasiodiplodia theobromae (SCUF-TP2016)}

Colony characterized by the presence of abundant woolly mycelium and colonies from olive-grey to dark grey. The colonies were initially white to pale grey becoming dark grey with age and with fluffy aerial mycelia and black pigment on the reverse side of plate.Pycnidia formed with septated paraphyses between the conidiogenous cells. Conidia size of $L$. theobromae isolates (Figs 4) were $21-31 \times 13-15 \mu \mathrm{m}(x=26.2 \times 14.2 \mu \mathrm{m})$. They were initially hyaline, thin-walled and one septated, cylindrical to sub ovoid in shape. They later turned dark brown, formed a single medium septum and became thick-walled with longitudinal striations on the inner surface. Mature conidia were ovoid with a broad and rounded apex and tapered at the base (Fig. 4). 


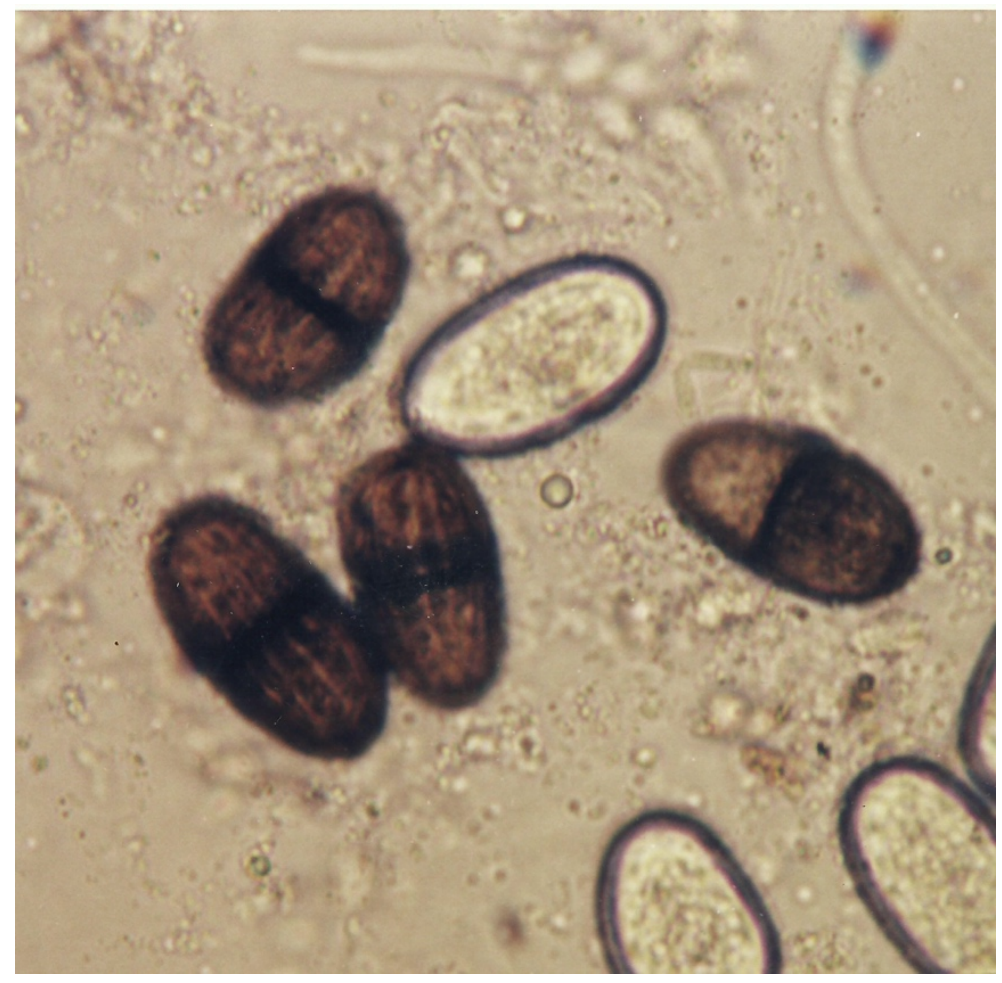

Fig. 4 - Conidia of L. theobromae (SCUF-TP2016).

\section{Partial purification}

Highly active fraction could be noticed at figure (4), where fraction number 18 recorded activity of $8.17 \mathrm{lMmL}^{-1} \mathrm{~min}^{-1}$ using Nessler's reaction and after pooling the positive fractions together we got an activity of $21.00 \mathrm{lMmL}^{-1} \mathrm{~min}^{-1}$ The one unit of enzyme is the amount of it catalyzed the formation of $1 \mu \mathrm{mol}$ ammonia per minute at $37^{\circ} \mathrm{C}$

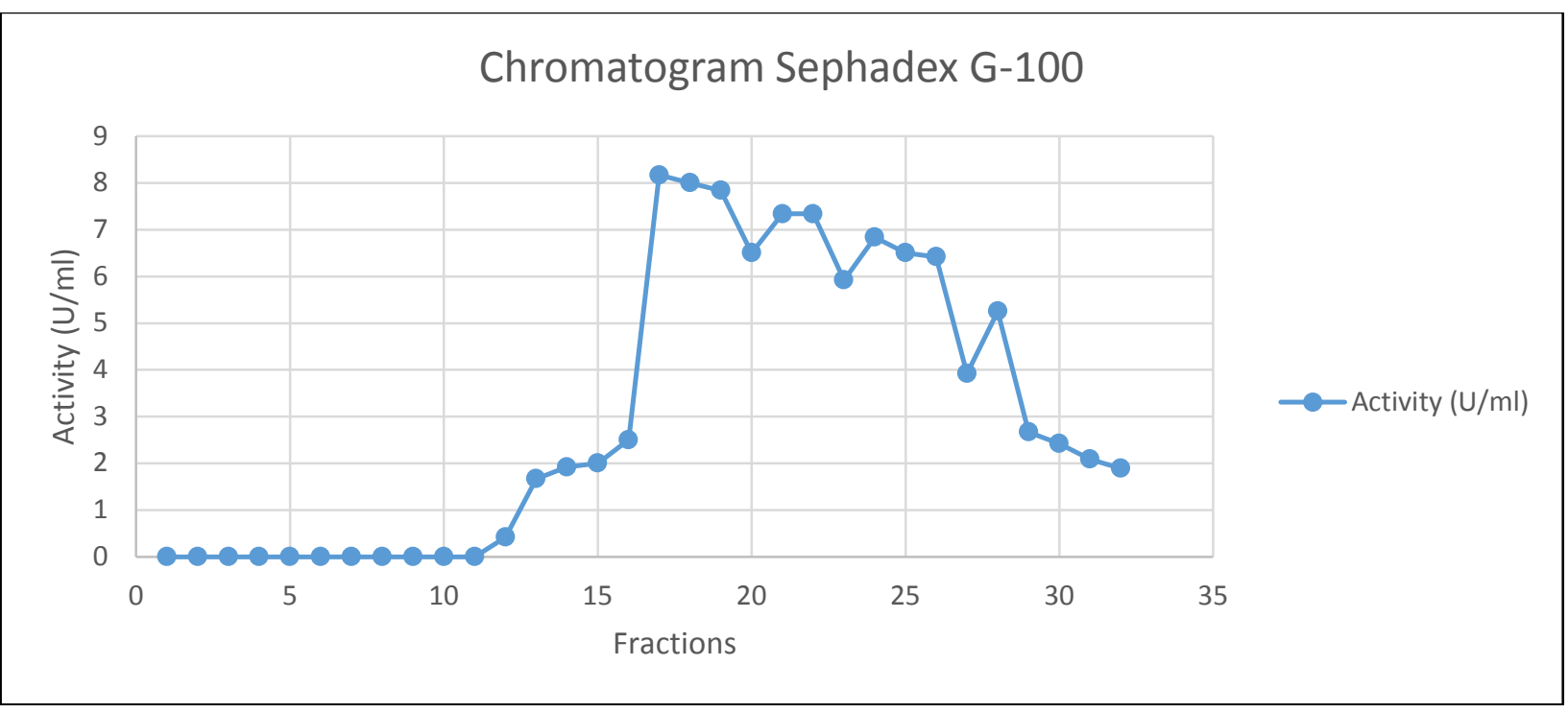

Fig. 4 - Asparaginase activity of Lasiodiplodia theobromae after Sephadex column G-100 purification. 


\section{Discussion}

Endophytic fungi considered as one of the most important bio-factories to produce several important chemical bio-active compound, which as; anticancer, antiviral, antiinflammatory and antimicrobial (Salem and Abdel-Azeem 2014; Abdel-Azeem et al. 2016, 2018).

Due to the high biodiversity showed at Saint Katherine protectorate, several studies have been carried to study the diversity of endophytic fungi associated with endemic and medicinal plants, our study recorded moderate counts of fungal populations and species diversity associated with Teucrium polium plant, which was similar to other studies carried out by several investigators at Saint Katherine protectorate (Abdel-Azeem 2009; Selim et al. 2011; AbdelAzeem and Salem 2012; Salem and Abdel-Azeem 2014; Abdel-Azeem et al. 2016).

Acute Lymphoblastic Leukemia (ALL) is widely distributed among children: $60 \%$ at the age of (0-14), $40 \%$ to other ages, several studies have been carried out to obtain a safe form of the L-Asparaginase out of fungal sources and they already succeed to get a safe forms of LAsparaginase (Asha and Pallavi 2012; Abbas Ahmed 2015; Kumar and Sobha 2012). Our results revealed that L-Asparaginase activity were recorded in three native species namely: Fusarium oxysporum, Fusarium solani and Lasiodiplodia theobromae. Our promising taxon is Lasiodiplodia theobromae which showed high production of L-Asparaginase with a remarkable activity (31.5 $\mathrm{lMmL}^{-1} \mathrm{~min}^{-1}$ ). Our results in agreement with Nagarajan et al.(2014) who recorded quite similar activity from the same species.

\section{Conflict of Interest}

The authors do not have any conflicts of interest.

\section{References}

Abbas Ahmed M. M. 2015. Production, purification and characterization of L-asparaginase from marine endophytic Aspergillus sp. ALAA-2000 under submerged and solid state fermentation. Journal of Microbial and Biochemical Technology, 7(3): 165-172. https://doi.org/10.4172/1948-5948.1000199

Abdel-Azeem A. M. 2009. Operation Wallacea in Egypt. I- A preliminary study on diversity of fungi in the world heritage site of Saint Katherine, Egypt. Assiut Univ. J. of Botany, 38(1): 29-54.

Abdel-Azeem A. M. and Salem F. M. 2012. Biodiversity of laccase producing fungi in Egypt. Mycosphere, 3(6): 900-920.

Abdel-Azeem A. M., Zaki S. M., Khalil W. F., Makhlouf N. A. and Farghaly L. M. 2016. Antirheumatoid activity of secondary metabolites produced by endophytic Chaetomium globosum. Frontiers in Microbiology, 7 (1477): 1-11.

Abdel-Azeem A. M., Omran M. A. and Mohamed R. A. 2018.. Evaluation of the curative probability of bioactive metabolites from endophytic fungi isolated from some medicinal plants against paracetamol-induced liver injury in mice. LAP LAMBERT Academic Publishing. ISBN: 978-613-9-89820-6.

Asha A. and Pallavi B. 2012. Production , purification and characterizationof extra cellular Lasparaginase having antineoplastic activity from Fusarium sp. Journal of Advance Researches in Biological Sciences, 4(4): 293-301.

Baskar G. and Renganathan S. 2009. Evaluation and screening of nitrogen source for Lasparaginase production by Aspergillus terreus MTCC 1782 using latin square design. Journal of Mathematics and Statistics, 1(2): 55-58.

Chow Y. and Ting A. S. Y. 2015. Endophytic L-asparaginase-producing fungi from plants associated with anticancer properties. Journal of Advanced Research, 6(6): 869-876. 
https://doi.org/10.1016/j.jare.2014.07.005

Dias F. F. G., Ruiz A. L. T. G., Torre A. and Sato H. H. 2016. Purification, characterization and antiproliferative activity of L-asparaginase from Aspergillus oryzae CCT 3940 with no glutaminase activity. Asian Pacific Journal of Tropical Biomedicine, 6(9): 785-794. https://doi.org/10.1016/j.apjtb.2016.07.007

Domsch K. H., Gams W. and Anderson T.-H. 2007. Compendium of Soil Fungi (2. ed., ta). Eching: IHW-Verl.

El-Nagga N. E.-A., El-Ewasy S. M. and El-Shweihy N. M. 2014. Microbial L-asparaginase as a potential therapeutic agent for the treatment of acute lymphoblastic leukemia: The Pros and Cons. International Journal of Pharmacology. https://doi.org/10.3923/ijp.2014.182.199

Ellis M. B. 1971. Dematiaceous hyphomycetes. Kew: Commonwealth Mycological Institute.

Ellis M. B. 1976. More dematiaceous hyphomycetes. Kew, Eng: Commonwealth Mycological Institute.

Guarro J., Gene J., Stchigel A. M., Figueras M. J. 2012. Atlas of soil ascomycetes. Issue 10 of CBS biodiversity series, Holland.

Gunatilaka A. A. L. 2006. Natural products from plant-associated microorganisms: distribution, structural diversity, bioactivity, and implications of their occurrence. Journal of Natural Products. https://doi.org/10.1021/np058128n

Kirk P. M. 2018. Index Fungorum database. Avaliable from: http://www.indexfungorum.org/names/Names.asp (accessed 7 August 2018)

Kirk PM, Ansell AE. 1992. Authors of Fungal Names. Kew: CAB International, 95 p.

Kirk P. M., Cannon P. F. and Minter D. W. 2008. Ainsworth and Bisby's Dictionary of the Fungi, 10th Edn. CAB International, Wallingford, UK.

Klich MA. 2002. Identification of common Aspergillus species. Centralbureau voor Schimmelcultures, Utrecht, Netherlands, 116 pp.

Kumar D. and Sobha K. 2012. L-Asparaginase from microbes: a comprehensive review. Advances in Bioresearch, 3: 137-157.

Kumar N. S. M., Ramasamy R. and Manonmani H. K. 2013. Production and optimization of L asparaginase from Cladosporium sp . using agricultural residues in solid state fermentation. Industrial Crops and Products, 43: 150-158. https://doi.org/10.1016/j.indcrop.2012.07.023

Kumar S., Dasu V. V. and Pakshirajan K. 2010. Localization and production of novel L asparaginase from Pectobacterium carotovorum MTCC 1428. Process Biochemistry, 45(2): 223-229. https://doi.org/10.1016/j.procbio.2009.09.011

Leslie J. F. and Summerell B. A. 2006. The Fusarium laboratory manual. 1st ed. Ames, Iowa: Blackwell Publishing

Mahajan R. V., Saran S., Saxena R. K. and Srivastava A. K. 2013. A rapid, efficient and sensitive plate assay for detection and screening of L-asparaginase-producing microorganisms. FEMS Microbiology Letters, 341(2): 122-126. https://doi.org/10.1111/1574-6968.12100

Mahajan R. V., Kumar V., Rajendran V., Saran S., Ghosh P. C. and Saxena R. K. 2014. Purification and characterization of a novel and robust L-asparaginase having lowglutaminase activity from Bacillus licheniformis: in vitro evaluation of anti-cancerous properties. PloS One, 9(6): e99037. https://doi.org/10.1371/journal.pone.0099037

Moharram A., Zohri A. N. and Seddek N. 2016. L-Asparaginase production by endophytic fungi isolated from Withania Somnifera in Egypt. SS International Journal of Multidisciplinary Research, 2: 30-40.

Nagarajan A., Thirunavukkarasu N., Suryanarayanan T. S. and Gummadi N. S. 2014. Screening and isolation of novel glutaminase free L-asparaginase from fungal endophytes. Research Journal of Microbiology, 9(4): 163-176.

Pandey P. K., Singh S., Yadav R. N. S., Singh A. K. and Chandra Kumar Singh M. 2014. Fungal 
endophytes: promising tools for pharmaceutical science. International Journal of Pharmaceutical Sciences Review and Research, 25(2): 128-138.

Pitt J. I. (1979). The genus Penicillium and its teleomorphic states Eupenicillium and Talaromyces. London; New York: Academic Press.

Salem F. M. and Abdel-Azeem A. M. 2014. Screening of anticancer metabolites produced by endophytic fungi. Saarbrücken: LAP LAMBERT Academic Publishing.

Sanjotha G. and Manawadi S. I. 2017. Isolation , screening , optimization and production of antitumor L-asparaginase by fungi from Karwar Coastal Region, 6(3): 1-7.

Sarquis M. I. de M., Oliveira E. M. M., Santos A. S. and Costa G. L. da. 2004. Production of Lasparaginase by filamentous fungi. Memorias Do Instituto Oswaldo Cruz, 99(5): 489-492. https://doi.org/10.1590/S0074-02762004000500005

Selim K. A., El-Beih A. A., Abdel-Rahman T. M. and El-Diwany A. I. 2011. Biodiversity and antimicrobial activity of endophytes associated with Egyptian medicinal plants. Mycosphere, 2: 669-678.doi:10.5943/mycosphere/ 2/6/7

Simmons E. G. 2007. Alternaria: an Identification manual. CBS biodiversity series 6. Utrecht: Centraalbureau voor Schimmelcultures

Strobel G. and Daisy B. 2003. Bioprospecting for microbial endophytes and their natural products. Microbiology and Molecular Biology Reviews, 67(4): 491-502. https://doi.org/10.1128/MMBR.67.4.491-502.2003

Suryanarayanan T. S., Thirunavukkarasu N. and Govindarajulu M. B. 2009. Fungal endophytes and bioprospecting. Fungal Biology Reviews, 23(1-2): 9-19. https://doi.org/10.1016/j.fbr.2009.07.001

Zhao J., Zhou L.,Wang J., Shan T., Zhong L., Liu X., et al. 2010. Endophytic fungi for producing bioactive compounds originally from their host plants, in Current Research, Technology and Education Topics in Applied Microbiology Microbial Biotechnology, ed. M. A.Vilas (Badajoz: Formatex Research Center), 567-576. 